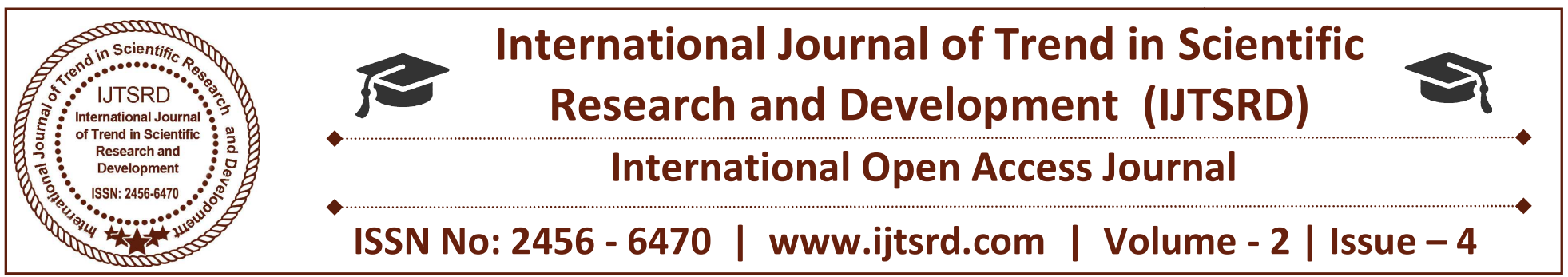

\title{
A Study on Retired Persons in Kashmir
}

\begin{abstract}
Sabahat Hussain
Research Scholar, Human

Development, Institute of Home

Science, University of Kashmir,

Jammu and Kashmir, India
\end{abstract}

\author{
Muzamil Jan \\ Sr. Assistant Professor, \\ Extension and Communication, \\ Institute of Home Science, \\ University of Kashmir, \\ Jammu and Kashmir, India
}

\author{
Naheed Vaida \\ Director, \\ Institute of Home Science, \\ University of Kashmir, \\ Jammu and Kashmir, India
}

\begin{abstract}
The present study is conducted to study the retired persons in Kashmir Valley and to compare the retired persons in Kashmir on the basis of their Gender and Dwelling. The study reveals that majority of the retired persons were from to district Srinagar, while as minimum number of retired persons belong to district Shopian. It is indicated that majority retired males and maximum retired females are found as per their gender. Majority of retired males belong to district Srinagar, followed by district Baramulla and district Anantnag. Majority of retired persons are found in rural areas, while as maximum number of retired persons are found in urban population. Majority of rural population are found in Baramulla district, followed district Anantnag.
\end{abstract}

Keywords: Retired Persons, Kashmir, Gender, Dwelling

\section{INTRODUCTION}

The word 'retire' means leave one's job and cease to work, especially because one has reached a particular age. Retirement is a period of restful activity or it can mean the loss of valued routines and sometimes outright boredom. Retirement is the act of retiring or the state of being retired. That is to with draw oneself from business public life or and to remove from active service. The transition to retirement, however, is frequently characterized as a multidimensional and dynamic process in which no two individuals are alike to have the same experience (Shultz \& Wang, 2011). The major life event in older adulthood is

retirement from work because it serves as a marker of the transition from pre-retirement midlife to the new life phase as sensor citizen (Ekert, 2010). The person is confronted with new social roles, challenges, expectations and opportunities, all of which in turn can influence the well being of a person. The most important personal factors that influence mainly retirement decisions are marital status, healthy condition and socio-economic situation, among others (Feldman, 1994). Large behavioural changes may occur after retirement, which is almost always a remarkable life event, as a consequence of shocks to time discounting, incomes or beliefs about the future. Transitioning out of the workforce represents one such critical moment for lifestyle modification. It is associated with changes in time flexibility and availability, social networks and contacts, financial security, income etc., all of which are related to lifestyle (Cutler and Glaeser, 2005). It is associated with changes in time flexibility and availability, social networks and contacts, financial security, income etc., all of which are related to lifestyle. Retirement may also bring opportunities to rethink habitual lifestyle and establish new routines in later life. Thus, transition into could provide a window of opportunity for positive behavioural changes.

\section{REVIEW OF LITERATURE}

Reseakotter and Garris (2001) conducted a study on the "relationship between retirement planning, use of time, and psychological adjustment to retirement. Significant differences were found when comparing with retirees, indicated they had done to prepare for retirement and what they believed after retirement was important for people to have done. Kim \& Moen 
(2002) conducted a longitudinal study and investigated the relationship between retirement transitions and subsequent psychological well being. The findings show that the relationship between retirement and psychological well being must be viewed in a temporal, life course context. Specifically, making the transition to retirement is associated with higher levels of morale whereas; being 'continuously' retired is related to greater depressive symptoms among men. Williamson and Shaffer (2001) studied the relationship between caregiver depression and abusive behavior directed toward the care recipient. Each participant was the primary caregiver to his or her spouse. The authors found a positive relationship between caregiver depression and abusive behaviours directed towards the care of the recipient. They also found that caregivers who were satisfied with their marriage prior to their spouse's illness reported less depressive symptoms and abusive behaviours. Insler (2014) and Eibich (2015) conducted a study on Understanding the effect of retirement on health \& the health consequences of retirement. It was found that, Retirement could have a negative impact on health because of a decrease in work-related physical exercise, loss of ambition or less engagement in social or intellectual activities, accelerating the decline in health due to ageing. Kim \& Feldman (2000) conducted a study on working in retirement: the antecedents of bridge employment and its consequences for quality of life in retirement. It was found that situation at the work place can have a significant impact on a person's decision to retire or continue to work. Retirement is increasingly recognized as one of the significant turning points in the life career of an individual, or least for the majority of adults who have spent all or much of the later part of their lives in the labor force.

\section{OBJECTIVES OF THE STUDY:}

1. To study the retired persons in Kashmir Valley.

2. To compare the retired persons in Kashmir on the basis of their Gender and Dwelling.

\section{RATIONALE OF STUDY:}

Retirement is regarding as a period of restful activity or it can mean the loss of valued routines and sometimes outright boredom. Retirement has been considered as one of the most important later life status transitions. The experience to retirement may promote a sense of well- being, as the employees move out of demanding or stressful jobs. But, on the other hand, the retirement passage may itself lead to deteriorated well being, as individuals lose their occupational attachments, their major anchor for their identities, their social network etc. The pre-retirees and workers are woefully unprepared for their retirement years. Most of the employees have insufficient savings to support themselves in retirement. Many households are unfamiliar even about the most basic economic concepts needed to make saving and investments decisions. Many people cannot afford to retire, since they prepared late for retirement. The present study is proposed because the retired persons are confronted with new personal and social roles, challenges, expectations and opportunities, all of which in turn can influence the well being of a person. Assessing retirement adjustment and psychological well being among retired persons in Kashmir will provide an insight into their overall life situations, problems faced by them, their coping strength and psychological well being.

\section{MATERIALS AND METHODS:}

The present study is conducted in Kashmir region. The study is based on whole population of retired persons from March 2008- 2017 for 10 years. For the present study secondary source of data has been used to collect the information. The main source of information was gathered from Accountant General Kashmir (AG's Office Kashmir).

\section{RESULTS AND DISCUSSION}

Table 1 depicts retired persons as per their Gender from March 2008-December 2017. Overall 33977 retired persons are found in all 10 Districts of Kashmir. Majority of the retired persons i.e. 40 per cent $(\mathrm{f}=13704)$ belong to Srinagar district, followed by 13.40 per cent $(\mathrm{f}=4554)$ retired persons belong to Baramulla district, 12.32 per cent $(\mathrm{f}=4189)$ retired persons belong to Anantnag district,7.58 per cent $(\mathrm{f}=2577)$ retired persons belong to district Budgam ,6.48 per cent $(\mathrm{f}=2205)$ retired persons belong to district Pulwama,6.32 per $\operatorname{cent}(\mathrm{f}=2150)$ retired persons belong to Kupwara district,4.29 per cent $(\mathrm{f}=1459)$ retired persons belong to Ganderbal district,3.31 per cent $(\mathrm{f}=1127)$ retired persons belong to district Bandipora,3per cent $(\mathrm{f}=1095)$ retired persons belong to district Kulgam and the remaining 3 per cent $(f=917)$ retired persons belong to district Shopian.

Table 2 reveals that overall 30663 retired Males and 3314 retired females are found in Kashmir. Majority i.e. 39 per cent $(\mathrm{f}=11982)$ retired males belong to 
district Srinagar,13.61 per cent $(\mathrm{f}=4174)$ belong to district Baramulla, 12.47 per cent $(\mathrm{f}=3825)$ belong to district Anantnag, 7.49 per cent $(\mathrm{f}=2299)$ belong to district Budgam, 7 per cent $(\mathrm{f}=2051)$ belong to Kupwara, 7 per cent $(\mathrm{f}=2037)$ belong to district Pulwama, 4.30 per $\operatorname{cent}(\mathrm{f}=1319)$ belong to district Ganderbal,3.47 per cent( $\mathrm{f}=1067)$ belong to district Bandipora,3.39 per cent $(\mathrm{f}=1041)$ belong to district Kulgam and the remaining 3 per cent $(\mathrm{f}=867)$ district Shopian. In comparison to males 52 per cent $(\mathrm{f}=1722)$ retired females belong to Srinagar district, 11 per cent $(f=379)$ belong to Baramulla, 11 per cent $(f=364)$ belong to Anantnag, 8 per $\operatorname{cent}(\mathrm{f}=278)$ belong to Budgam, 5 per $\operatorname{cent}(\mathrm{f}=168)$ belong to district Pulwama, 4 per cent $(\mathrm{f}=140)$ belong to Ganderbal. Only 3 per cent $(\mathrm{f}=99)$ retired females belong to district Kupwara, 2 per cent ( $\mathrm{f}=60$ ) from Bandipora, 2 per cent $(\mathrm{f}=54)$ from Kulgam and 2 per cent $(\mathrm{f}=50)$ from Shopian.

Table 3,depicts that overall population under rural areas is 16943.Majority of the retired persons i.e., 22 per cent $(\mathrm{f}=3710)$ belong to district Baramulla, followed by 18.27 per $\operatorname{cent}(\mathrm{f}=3097)$ belong to Anantnag district, 13.08 per $\operatorname{cent}(\mathrm{f}=2217)$ belong to district Budgam, 11.36 per $\operatorname{cent}(\mathrm{f}=1925)$ belong to district Pulwama , 11.34 per cent $(\mathrm{f}=1922)$ belong to district Kupwara, 7.27 per $\operatorname{cent}(\mathrm{f}=1233)$ belong to district Ganderbal , 5.44 per cent $(\mathrm{f}=923)$ belong to district Bandipora, 5.23 per cent belong to district Kulgam , 5.08 per cent $(\mathrm{f}=861)$ belong to Shopian. Only 1 per cent $(\mathrm{f}=168)$ retired persons are from district Srinagar. In comparison to rural population, overall population under Urban areas are 17034.Majority of the Urban population i.e., 79.46 per cent $(\mathrm{f}=13536)$ belong to district Srinagar, 6.41 per cent belong to district Anantnag, followed by 5 per cent $(\mathrm{f}=844)$ belong to district Baramulla, 2.11 per cent $(\mathrm{f}=360)$ from district Budgam, 1.64 per cent $(\mathrm{f}=280)$ belong to district Pulwama, 1.33 per cent $(\mathrm{f}=228)$ belong to district Kupwara 1.32 per cent $(\mathrm{f}=226)$ belong to district Ganderbal , 1.22 per cent $(\mathrm{f}=208)$ belong to district Kulgam, 1.19 per cent $(\mathrm{f}=204)$ belong to district Bandipora and the remaining 0.32 per cent $(\mathrm{f}=56)$ retired persons were belong to district Shopian.
Table 1: Retired Persons in all Districts of Kashmir:

\begin{tabular}{|l|l|l|}
\hline \multicolumn{1}{|c|}{ District } & \multicolumn{1}{c|}{$\begin{array}{c}\text { Total Retired } \\
\text { Persons }\end{array}$} & \multicolumn{1}{c|}{ \%age } \\
\hline Anantnag & 4189 & 12.32 \\
\hline Bandipora & 1127 & 3.31 \\
\hline Baramulla & 4554 & 13.40 \\
\hline Budgam & 2577 & 7.58 \\
\hline Ganderbal & 1459 & 4.29 \\
\hline Kupwara & 2150 & 6.32 \\
\hline Kulgam & 1095 & 3 \\
\hline Pulwama & 2205 & 6.48 \\
\hline Srinagar & 13704 & 40 \\
\hline Shopian & 917 & 3 \\
\hline Total & 33977 & 100 \\
\hline
\end{tabular}

Source Accountant General Kashmir: March 2008December 2017

Table 2: Retired Persons as per their Gender

\begin{tabular}{|l|l|l|l|l|}
\hline \multicolumn{1}{|c|}{ District } & $\begin{array}{c}\text { Males } \\
(\mathbf{N})\end{array}$ & $\begin{array}{c}\text { Females } \\
(\mathbf{N})\end{array}$ & $\begin{array}{c}\% \\
\text { age }\end{array}$ \\
\hline Anantnag & 3825 & 12.47 & 364 & 11 \\
\hline Bandipora & 1067 & 3.47 & 60 & 2 \\
\hline Baramullah & 4175 & 13.61 & 379 & 11 \\
\hline Budgam & 2299 & 7.49 & 278 & 8 \\
\hline Ganderbal & 1319 & 4.30 & 140 & 4 \\
\hline Kupwara & 2051 & 7 & 99 & 3 \\
\hline Kulgam & 1041 & 3.39 & 54 & 2 \\
\hline Pulwama & 2037 & 7 & 168 & 5 \\
\hline Srinagar & 11982 & 39 & 1722 & 52 \\
\hline Shopian & 867 & 3 & 50 & 2 \\
\hline Total & 30663 & 100 & 3314 & 100 \\
\hline
\end{tabular}

Source Accountant General Kashmir: March 2008December 2017

Table 3: Retired Persons on the basis of Dwelling

\begin{tabular}{|l|l|l|l|l|}
\hline \multicolumn{1}{|c|}{ District } & \multicolumn{1}{|c|}{ Rural } & \multicolumn{1}{c|}{ \%age } & \multicolumn{1}{c|}{ Urban } & \multicolumn{1}{c|}{ \%age } \\
\hline Anantnag & 3097 & 18.27 & 1092 & 6.41 \\
\hline Bandipora & 923 & 5.44 & 204 & 1.19 \\
\hline Baramulla & 3710 & 22 & 844 & 5 \\
\hline Budgam & 2217 & 13.08 & 360 & 2.11 \\
\hline Ganderbal & 1233 & 7.27 & 226 & 1.32 \\
\hline Kupwara & 1922 & 11.34 & 228 & 1.33 \\
\hline Kulgam & 887 & 5.23 & 208 & 1.22 \\
\hline Pulwama & 1925 & 11.36 & 280 & 1.64 \\
\hline Srinagar & 168 & 1 & 13536 & 79.46 \\
\hline Shopian & 861 & 5.08 & 56 & 0.32 \\
\hline Total & 16943 & 100 & 17034 & 100 \\
\hline
\end{tabular}

Source Accountant General Kashmir: March 2008December 2017 


\section{SUMMARY AND CONCLUSION}

Retirement is a period of restful activity or it can mean the loss of valued routines. Retired persons are confronted with new social and personal roles, new challenges which in turn can influence the well being of a person. Retirement is characterized as a multidimensional and dynamic process in which no two individuals are alike to have the same experience. Majority of the retired persons were from to district Srinagar, while as minimum number of retired persons belong to district Shopian. It is indicated that majority retired males and maximum retired females are found as per their gender. Majority of retired males belong to district Srinagar, followed by district Baramulla and district Anantnag. Majority of retired persons are found in rural areas, while as maximum number of retired persons are found in urban population .Majority of rural population are found in Baramulla district, followed district Anantnag. Minimum rural populations are found in district Shopian. Majority of the urban population are found in district Srinagar, followed by district Anantnag. Retirees financial, physical and psychological well being has important influences on their longetivity and morality. They also influence retirees work related behaviours. It was found that, workers who had participated in the pre- retirement plans/ programs adjusted better than those who have not. Retirement is increasingly recognized as one of the significant turning points in the life career of an individual, or least for the majority of adults who have spent all or much of the later part of their lives in the labor force. Attitude toward retirement has been found to influence employees' decision to retire, in one's planning for retirement and in one's satisfaction with retirement (Adams \& Lax, 2002).

\section{REFRENCES}

1. Adams GA, Prescher J, Beehr TA, Lepisto L.(2002). Applying work- role attachment theory to retirement decision-making. int. j. Aging Hum.Dev.54:125-37.

2. Atchley, R. C. (1976). Selected social and psychological differences between men and women in later life". Journal of Gerontology 31:204-221.

3. Cutler, David M. and Edward Glaeser. (2005). "What Explains Differences In Smoking, Drinking, And Other Health-Related Behaviors?" American Economic Review, 2005, v95 (2, May), 238-242.
4. Eibich, P., (2015). Understanding the effect of retirement on health: Mechanisms and heterogeneity. Journal of Health Economics, 43, 1-12.

5. Feldman DC. (1994). The decision to retire early. A review and conceptual ization. Acad. Manag. Rev.19:285-311.

6. Greene, M. R., H. C, Pyron, U. V. Manion, H. Winklevoss. (1969). Pre-retirement counseling, Retirement Adjustment and the older employee. Washington, DC: ADA.

7. Insler, M., 2014. The health consequences of retirement. Journal of Human Resources, 49(1),195-233.

8. Jungmeen E. Kim and Phyllis Meon. (2002). Retirement transitions, Gender and Psychological well being. A Life course, Ecological ModelJournal of Gerontology: Psy.Sciences.vol.57B, No.3, and p212-p222

9. Kim. S, Feldman DC. (2000). working in retirement: the antecedents of bridge employment and its consequences for quality of life in retirement.Acad.Manag.43:1195-210.

10. Lundberg, U. (2006). Stress, subjective and objective health, International journal of social welfare, vol5, 41-48

11. Meon, P., Kim, J. E., \& Hofmeister, H. (2001). Couples' Work/retirement transitions, gender and marital quality, Social Psychology Quarterly, 64, 55-71.

12. Pin quart M, Schindler I. (2007). Changes of life satisfaction in the transition to retirement: a latent class approach. Psychol. Aging 22: 442-55.

13. Shultz KS \& Wang M. (2011). Psychological perspective on the changing nature of retirement.Am.psychol.66:170-79.

14. Tytherleigh, M. Y., Jacobs, P. A., Webb, C., Ricketts, C., \& Cooper, C. (2007). Gender, Health, and stress in English university staff exposure or vulnerability? Applied Psychology: An International Review, 56, 267-287.

15. Williamson, G. M., \& Shaffer, D. R (2001). Relationship quality and potentially harmful behaviors' by spousal caregivers: How we were then, how we are now. Psychology and Aging, 16, 217-226. 